\title{
Study of Anorectal Manometry changes in Anal Fissure
}

H.S.Tawfik, E.M.Abdel Hafez, A.M.Saeed, S.G.Ibrahim and Y.A.Hanna

General Surgery Dept., Faculty of Medicine, Benha Univ., Benha, Egypt

E-Mail:Y.H@yahoo.com

\begin{abstract}
Nowadays, wide range of population experience proctologic pathologies at least once in their lives. $10-15 \%$ of proctologic pathologies patients suffer from anal fissure that impair their usual life. So it is mandatory to know how to achieve effective treatment for anal fissure. Aim of Study: The aim of this study is to establish any predictive value of anorectal manometry in assessing the effectiveness of anal fissure treatment.Patients and Methods: This is a prospective study done on 30 patients recruited from outpatient clinic in Benha University divided into two groups whereas group (A) included 15 patients with acute anal fissure (less than six weeks from onset of disease), and group (B) included 15 patients with chronic anal fissure (more than six weeks from onset of disease). Anomanometry was done for all patients and the results were compared.Results: patients with acute anal fissure showed normotensive anal resting pressure (Mean \pm SD $50.8 \pm 5.76 \mathrm{mmHg}$ in males and $64.4 \pm$ $5.81 \mathrm{mmHg}$ in females), while those with chronic anal fissure showed high resting pressure (Mean \pm SD $88.3 \pm 6.18 \mathrm{mmHg}$ in females and $88.65 \pm 1.05 \mathrm{mmHg}$ in males).Conclusion: we can conclude that acute anal fissure disease is not usually associated with elevated resting anal pressure but chronic anal fissure is usually associated with hypertensive anal resting pressure in majority of patients. These manometric findings may explain why most cases of acute case anal fissure can be treated medically while cases with chronic anal fissure usually need surgical intervention that liberates anal pressure from hypertensive state to normotensive state. We also can predict that patients with chronic anal fissure associated with normotensive resting anal pressure may be treated either medically or surgically without doing internal sphincterotomy.
\end{abstract}

\section{Introduction}

Wide range of population nowadays -about 30-40\%experience proctologic pathologies at least once in their lives. $10-15 \%$ of proctologic pathologies patients suffer from anal fissure [1].

An anal fissure, or fissure-in-ano, is an oval, ulcerlike, longitudinal tear in the anal canal, distal to the dentate line (injury to lining epithelium) [2].

Although the exact incidence is unknown, it is a common disorder, with equal gender distribution. Fissures can occur at any age, but are usually seen in younger and middle-aged adults. In almost $90 \%$ of the cases, fissures are identified in the posterior midline, but can be seen in the anterior midline in up to $25 \%$ of affected women and $8 \%$ of affected men. An additional $3 \%$ of patients have both anterior and posterior fissures. Fissures occurring in lateral positions should raise suspicions for other disease processes, such as Crohn's disease, tuberculosis, syphilis, human immuno-deficiency virus (HIV)/ acquired immunodeficiency syndrome (AIDS), or anal carcinoma [3].

Etiopathogenesis of anal fissure are anal sphincter hypertonia, anal sphincter fibrosis, traumata, anal abuse, anal sexual practices, infection, ischemia and anatomical causes. Patients with anal fissure may complain from anorectal pain, anal bleeding, anal pruritus and constipation. Anal fissure is subdivided into primary anal fissure (acute and chronic) and secondary anal fissure (associated with ulcerative colitis, crohn's disease, induced by many infections, drug induced and other causes) [4].

As patients with anal fissure may have anal sphincter hypertonia, they have been subjected to do anorectal manometry, which is a test that measures the pressures of the anal sphincter muscles [5], the sensation in the rectum and the neural reflexes that are needed for normal bowel movements. The test takes approximately 30 minutes and patients have been asked to change into a hospital gown. A technician or a nurse explained the procedure to them, took a brief health history, and answered any questions they might have had.

The patients then lied on their left side and a small flexible tube about the size of a thermometer with a balloon at the end was inserted into the rectum, the catheter was connected to a machine that measures the pressure, during the test the small balloon attached to the catheter might have been inflated in the rectum to assess the normal reflex pathways. The nurse or the technician may have also asked the patients to squeeze by tightening the sphincter muscles as if trying to prevent anything from coming out, relax, or push by straining down as if trying to have a bowel movement at various times. The anal sphincter muscle pressures were measured during each of these maneuvers [6].

Anorectal sphincter manometry provides an objective assessment of anorectal sphincter mechanism. It provides more reliable indicator of the anal sphincter tone than what can be achieved by digital examination. The relative contribution of voluntary and involuntary component of sphincter tone can be assessed by anorectal manometry which can differentiate functional disorder from organic anorectal disorder [7].

Treatment of anal fissure depends on whether it is acute or chronic, anorectal manometry, clinical examination and full history taken, and depending on all the previously mentioned, the surgeon can decide the line of treatment to be either conservative or surgical.

Treatment of acute anal fissure includes basic therapy, self- bougienage, and local therapy [1]. Treatment of chronic anal fissure sub-divided into conservative and surgical. [8, 4] Physician nowadays encourage nonsurgical approach for treatment of anal fissure [1].

\section{Patients and methodology}

Thesis study done on patients $(n=30)$ recruited from outpatient clinic in Benha University Hospital. Patients were divided into two groups whereas group (A) included 
15 patients with acute anal fissure (less than six weeks from onset of disease), and group (B) included 15 patients with chronic anal fissure (more than six weeks from onset of disease and associated clinical criteria of chronicity).

\subsection{Material and methods}

This is a prospective study included patients with acute and chronic anal fissures conducted at the Department of General Surgery of Benha university Hospital,

(2017 to 2019).

Study was approved by hospital's Ethics Committee.

\subsection{The exclusion criteria werE}

Patients refusing to do anorectal manometry (ARM)

Patients with previous anorectal operations

\subsection{Clinical data of all patients}

Patients with anal stenosis

Patient complaining from signs of Crohn's or ulcerative colitis

Bleeding per rectum

Accompanied by peri anal abscess

Radiotherapy and anorectal malignancies.

Patients with chronic anal fissure, 4 males, 11 females, with acute anal fissure, 5 males, 10 females who fulfilled pre-designed inclusion criteria were enrolled.

Preparation: Specific patient preparation by enema prior to manometery test was required.

Technique: Rectal examination was performed in left lateral position and subjective assessment of anal sphincter tone noted.

Manometric evaluations were performed with HRARM

Table (1) clinical data of the studied group.

\begin{tabular}{|c|c|c|c|c|c|c|c|c|c|c|c|c|c|c|c|c|c|}
\hline \multirow{2}{*}{\multicolumn{2}{|c|}{$\begin{array}{l}\text { Sex } \\
\text { Females }\end{array}$}} & \multicolumn{4}{|c|}{ Age } & \multicolumn{6}{|c|}{ Main symptoms } & \multicolumn{6}{|c|}{ Site of anal fissures } \\
\hline & & \multicolumn{2}{|c|}{ Males } & \multicolumn{2}{|c|}{ Females } & \multicolumn{2}{|c|}{ Males } & \multicolumn{2}{|c|}{ Pain } & \multicolumn{2}{|c|}{ Bleeding } & \multicolumn{2}{|c|}{ Anterior } & \multicolumn{2}{|c|}{ Posterior } & \multicolumn{2}{|c|}{ Combined } \\
\hline $\begin{array}{l}\text { Acu } \\
\text { te }\end{array}$ & $\begin{array}{c}\text { Chro } \\
\text { nic }\end{array}$ & $\begin{array}{c}\text { Acu } \\
\text { te }\end{array}$ & $\begin{array}{c}\text { Chro } \\
\text { nic }\end{array}$ & $\begin{array}{c}\text { Acu } \\
\text { te }\end{array}$ & $\begin{array}{c}\text { Chro } \\
\text { nic }\end{array}$ & $\begin{array}{c}\text { Acu } \\
\text { te }\end{array}$ & $\begin{array}{c}\text { Chro } \\
\text { nic }\end{array}$ & $\begin{array}{c}\text { Acu } \\
\text { te }\end{array}$ & $\begin{array}{c}\text { Chro } \\
\text { nic }\end{array}$ & $\begin{array}{c}\text { Acu } \\
\text { te }\end{array}$ & $\begin{array}{l}\text { Chro } \\
\text { nic }\end{array}$ & $\begin{array}{c}\text { Acu } \\
\text { te }\end{array}$ & $\begin{array}{c}\text { Chro } \\
\text { nic }\end{array}$ & $\begin{array}{c}\text { Acu } \\
\text { te }\end{array}$ & $\begin{array}{c}\text { Chro } \\
\text { nic }\end{array}$ & $\begin{array}{c}\mathrm{Acu} \\
\text { te }\end{array}$ & $\begin{array}{c}\text { Chro } \\
\text { nic }\end{array}$ \\
\hline 10 & 11 & 5 & 4 & $\begin{array}{c}25- \\
40\end{array}$ & $\begin{array}{c}25- \\
62\end{array}$ & $\begin{array}{c}23- \\
30\end{array}$ & $\begin{array}{l}34- \\
44\end{array}$ & 15 & 15 & 15 & 7 & 5 & 3 & 9 & 8 & 1 & 4 \\
\hline
\end{tabular}

Clinical history and examination showed that all patients with acute anal fissure $(100 \%)$ suffered from pain and bleeding or blood with stool. Five patients $(33.33 \%)$ had anterior anal fissure and 9 patients $(60 \%)$ had posterior anal fissure while only one patient $(6.66 \%)$ had combined anterior and posterior anal fissures. All patients with chronic anal fissure $(100 \%)$ were complaining from pain and only 7 patients $(46.66 \%)$ were complaining from repeated bleeding at defecation. There were three patients (20\%) who showed anterior chronic anal fissure, 8 patients $(53.33 \%)$ showed posterior fissure and 4 patients $(26.66 \%)$ showed combined anterior and posterior anal fissures as Shown in Table (1).

\section{Results}

3.1 Demographic data of the studied group

Table (2) Demographic data of males with acute anal pressure.

\begin{tabular}{lll}
\hline Number of patients & \% to patient group & \% to all patient \\
\hline $\mathbf{5}$ & $33.33 \%$ & $16.66 \%$ \\
\hline
\end{tabular}

Male patients with acute anal fissure percentage.

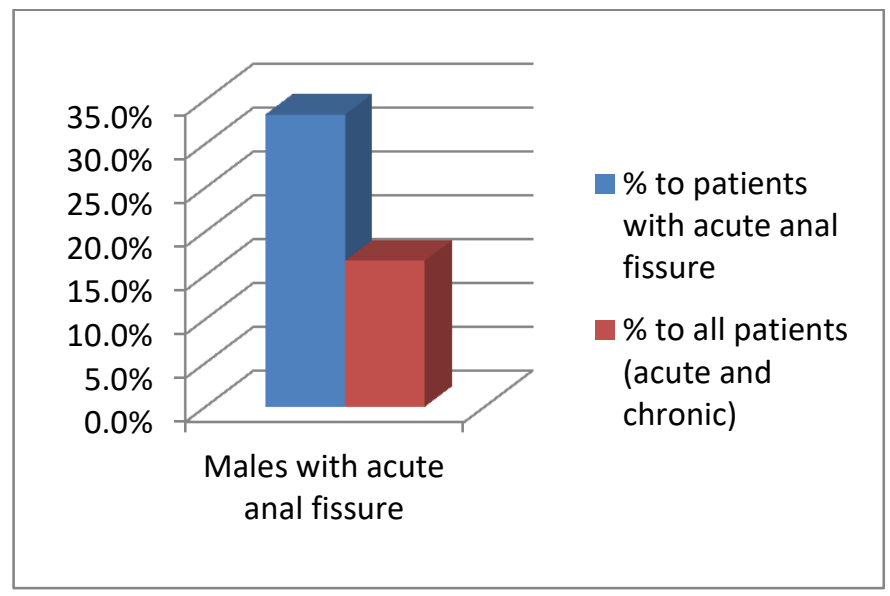

Fig (1) percentage of males with acute anal fissure in comparison to patients with acute anal fissure, and all patients with anal fissures (acute and chronic). 
Table (3) Demographic data of males with acute anal pressure.

\begin{tabular}{lll}
\hline Demographic data & Range & Mean \pm SD \\
\hline RAP & $36.8-54.2 \mathrm{mmHg}$ & $50.8 \pm 5.766 \mathrm{mmHg}$ \\
MRAP & $56.8-69.9 \mathrm{mmHg}$ & $68.2 \pm 6.87 \mathrm{mmHg}$ \\
Max RAP & $61.1-92.5 \mathrm{mmHg}$ & $67.2 \pm 15.89 \mathrm{mmHg}$ \\
\hline
\end{tabular}

Range and Mean \pm SD of RAP, MRAP and Max RAP of 5 males with normotensive and hypotensive acute anal fissure.

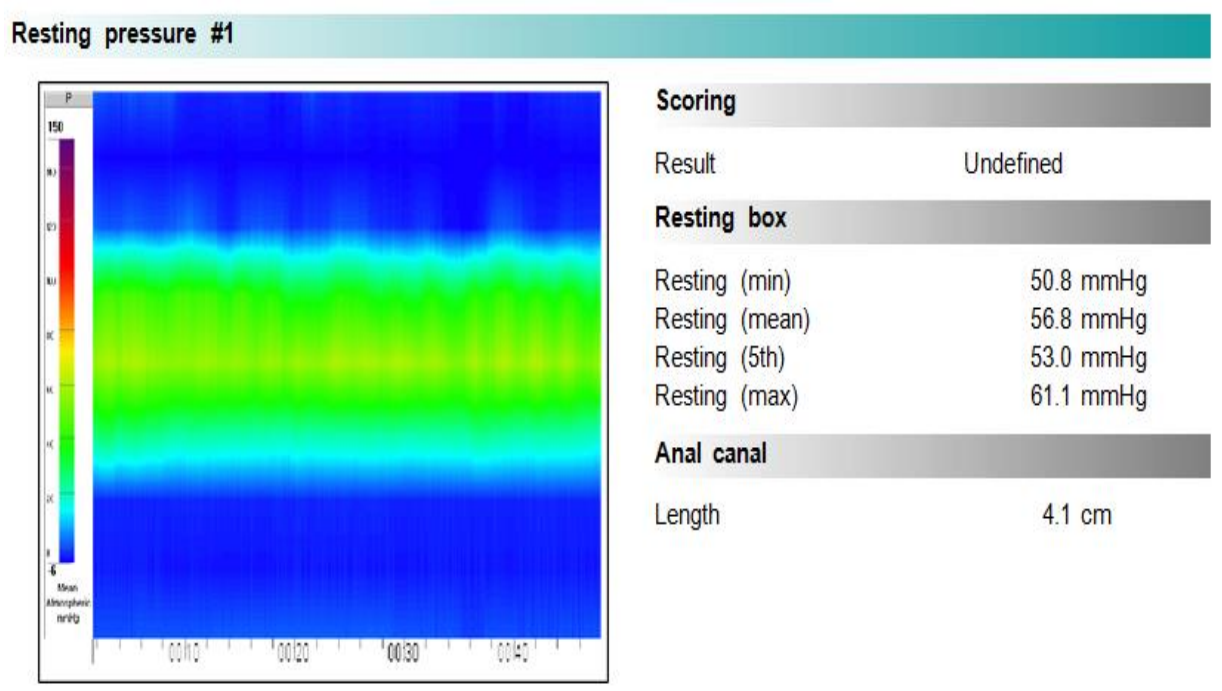

Fig (2) Normotensive resting pressure of a male patient with acute anal fissure.

Table (4) Demographic data of females with acute anal fissure.

\begin{tabular}{lcc}
\hline Number of patients & \% to patient group & \% to all patient \\
\hline $\mathbf{1 0}$ & $66.66 \%$ & $33.33 \%$ \\
\hline
\end{tabular}

Female patients with acute anal fissure percentage.

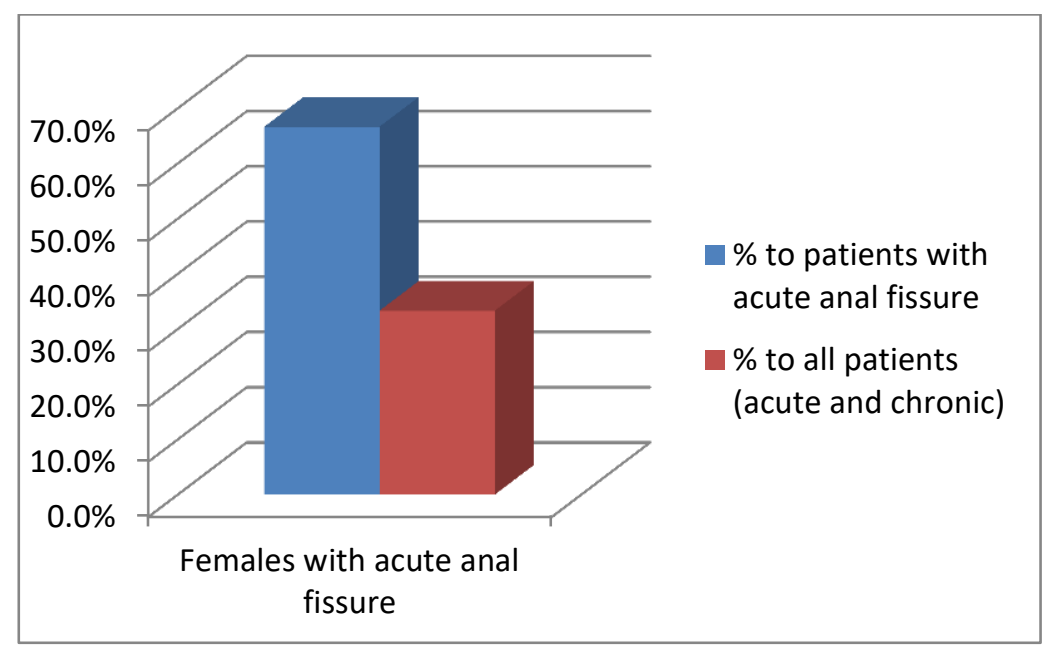

Fig (3) Percentage of females with acute anal fissure in comparison to patient with acute anal fissure and all patients with anal fissures (acute and chronic). 
Table (5) Demographic data of females with acute anal fissure.

\begin{tabular}{|c|c|c|}
\hline Demographic data & Range & Mean \pm SD \\
\hline$\overline{\mathbf{R A P}}$ & $\begin{array}{c}54.4-73.1 \\
\mathrm{mmHg}\end{array}$ & $64.4 \pm 5.81 \mathrm{mmHg}$ \\
\hline MRAP & $\begin{array}{c}70.8-83.3 \\
\mathrm{mmHg}\end{array}$ & $\begin{array}{c}76.45 \pm \\
4.197 \mathrm{mmHg}\end{array}$ \\
\hline Max RAP & $\begin{array}{c}94.2-105.7 \\
\mathrm{mmHg}\end{array}$ & $100.5 \pm 3.47 \mathrm{mmHg}$ \\
\hline
\end{tabular}

Range and Mean \pm SD of RAP, MRAP and Max RAP of 10 females with normotensive acute anal fissure

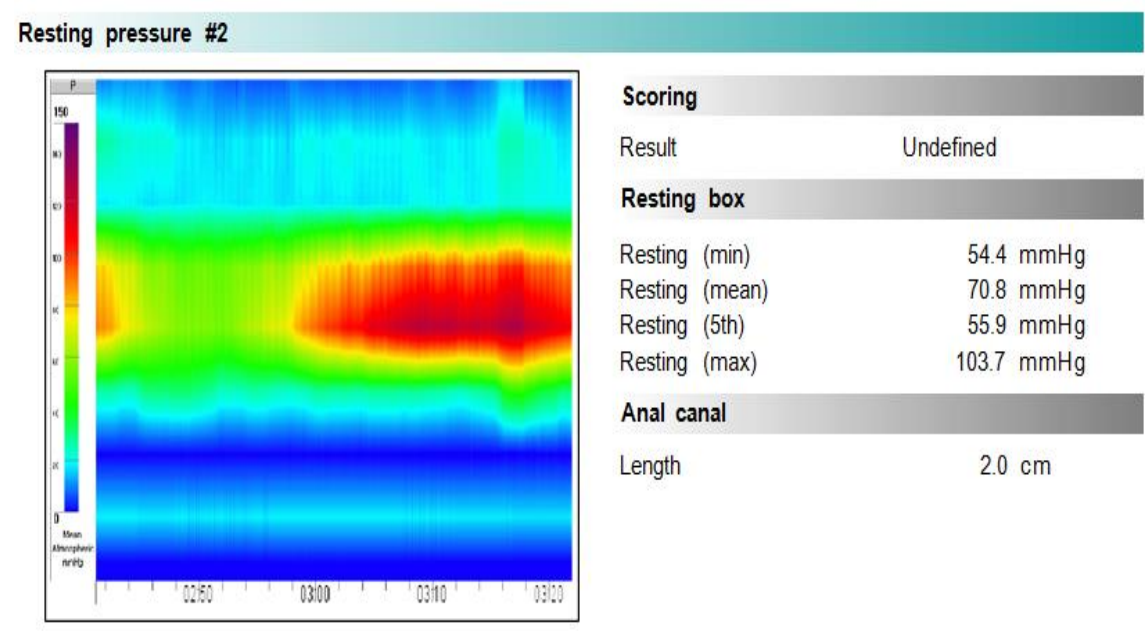

Fig (4) Normotensive resting pressure of a female patient with acute anal fissure.

Table (6)Demographic data of males with chronic anal fissure.

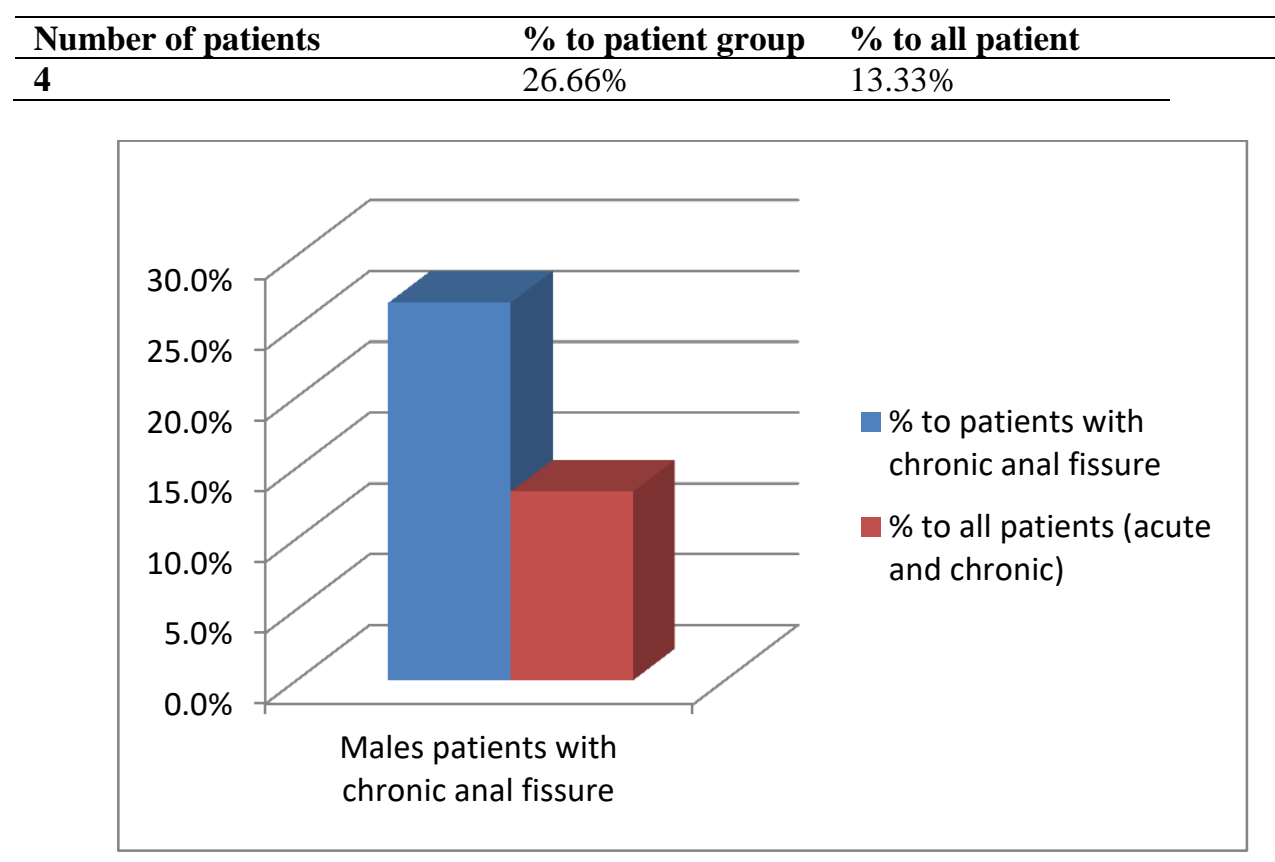

Fig (5) Percentage of males with chronic anal fissure in comparison to patients with chronic anal fissure and all patients with anal fissures (acute and chronic). 
Table (7) Demographic data of males with chronic anal fissure.

\begin{tabular}{lcc}
\hline Demographic data & Range & Mean \pm SD \\
\hline RAP & $86.9-89.7 \mathrm{mmHg}$ & $88.65 \pm 1.05 \mathrm{mmHg}$ \\
MRAP & $97.7-102.1 \mathrm{mmHg}$ & $100.6 \pm 1.87 \mathrm{mmHg}$ \\
Max RAP & $107.5-121.4 \mathrm{mmHg}$ & $117.3 \pm 6.87 \mathrm{mmHg}$ \\
\hline
\end{tabular}

Range and Mean \pm SD of RAP, MRAP and Max RAP of 4 males with chronic anal fissure showing hypertensive RAP.

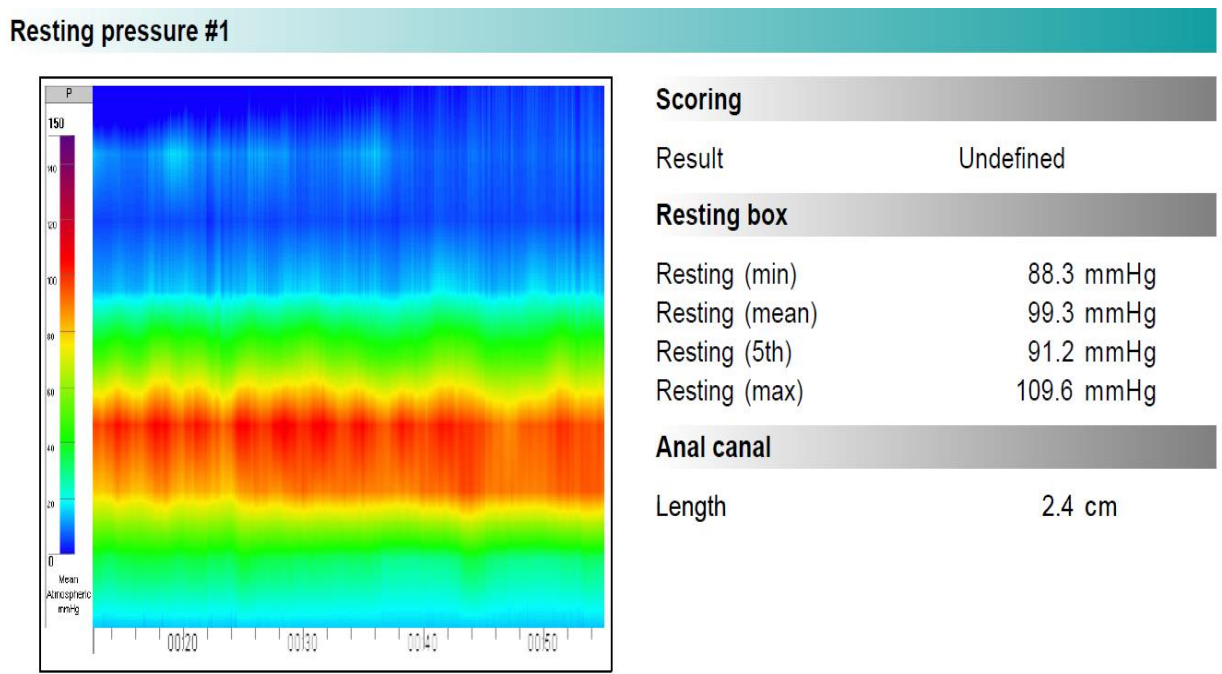

Fig (6) Hypertensive resting pressure of a male patient with chronic anal fissure.

Table (8) Demographic data of females with chronic anal fissure.

\begin{tabular}{lcc}
\hline Number of patients & \% to patient group & \% to all patient \\
\hline 11 & $73.33 \%$ & $36.66 \%$ \\
\hline
\end{tabular}

Females patients with chronic anal fissure percentage.

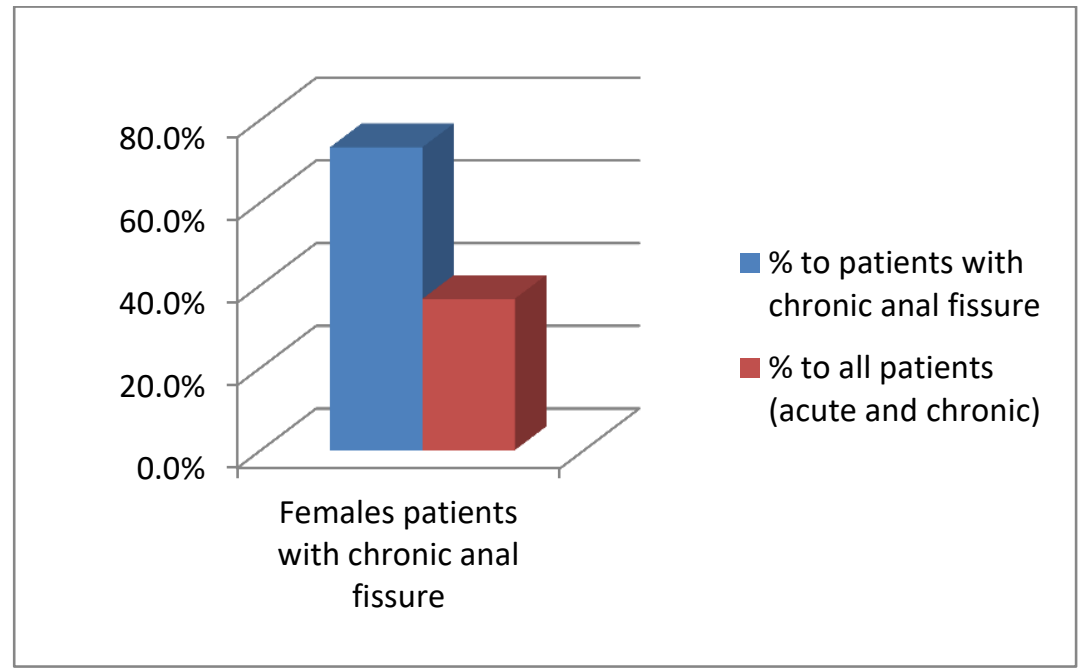

Fig (7) Percentage of females with chronic anal fissure in comparison to patients with chronic anal fissure and all patients with anal fissures (acute and chronic). 
Table (9) Demographic data of females with chronic anal fissure.

\begin{tabular}{lcc}
\hline Demographic data & Range & Mean \pm SD \\
\hline RAP & $80.1-99.3 \mathrm{mmHg}$ & $88.3 \pm 6.18 \mathrm{mmHg}$ \\
MRAP & $92.4-123.2 \mathrm{mmHg}$ & $102.5 \pm 10.013 \mathrm{mmHg}$ \\
Max RAP & $107.1-144.3 \mathrm{mmHg}$ & $114 . \pm 13.2 \mathrm{mmHg}$ \\
\hline
\end{tabular}

Range and Mean \pm SD of RAP, MRAP and Max RAP of 11 females with chronic anal fissure showing high normotensive and hypertensive RAP.

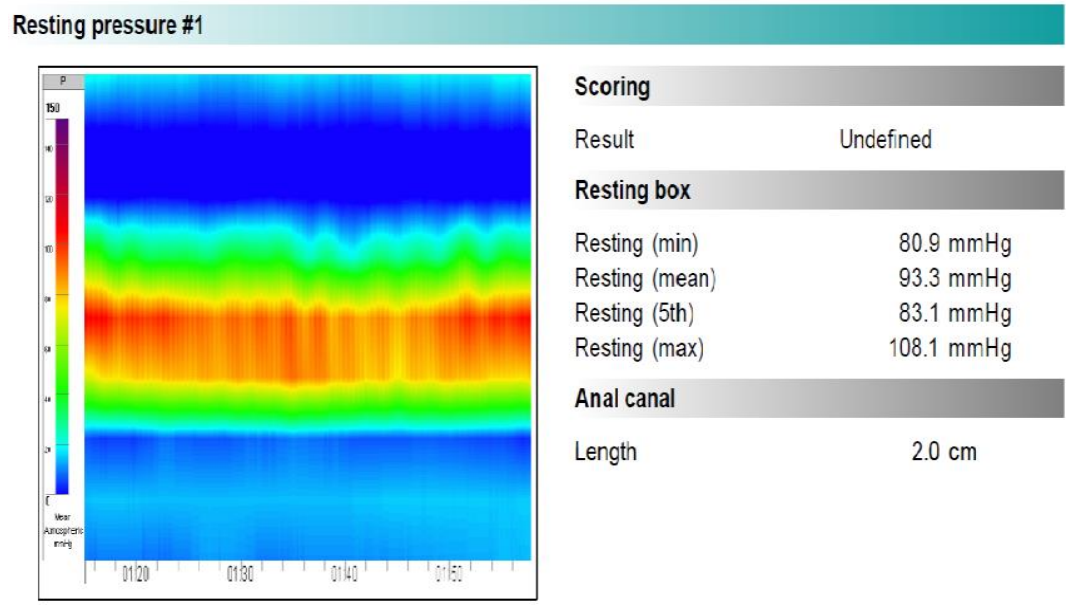

Fig (8) Normotensive resting pressure of a female patient with chronic anal fissure.

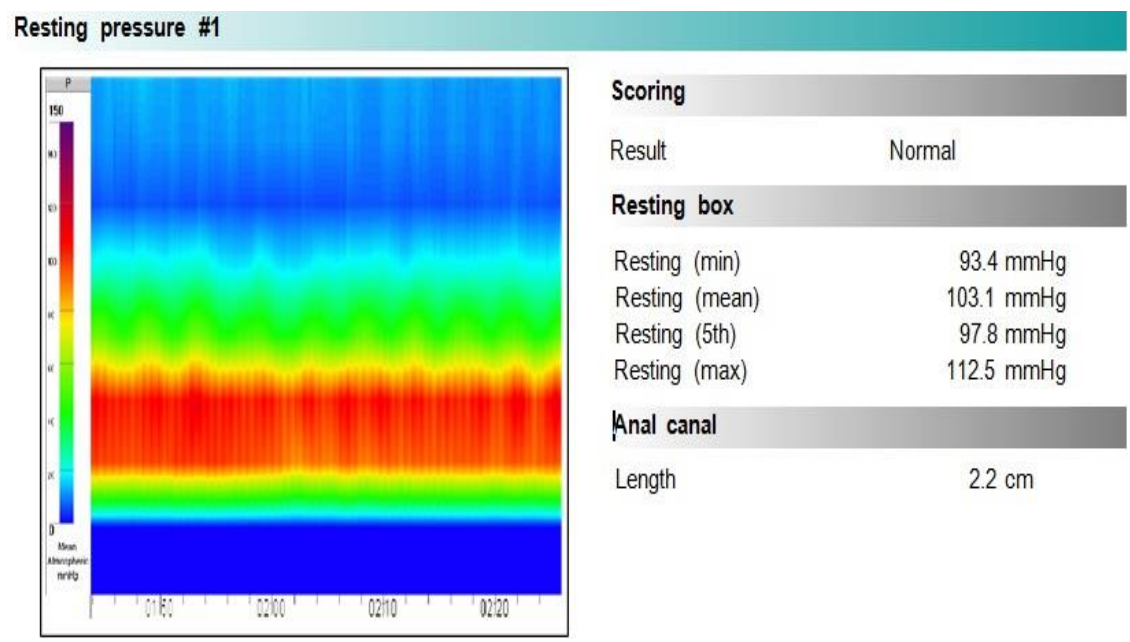

Fig (9) Hypertensive resting pressure of a female patient with chronic anal fissure.

Study was conducted on 30 patients divided into two groups. Group A were patients with acute anal fissures and included 10 females with acute anal fissures and represent $33.33 \%$ of all patients and $66.66 \%$ of patients with acute anal fissure and their ages ranged from 25 - 40 years old with Mean \pm SD $33 \pm 4.7$ years Shown in Table (4).

Results of anorectal manometry showed RAP resting anal pressure (ranges from $54.4-73.1 \mathrm{mmHg}$ ) and it's Mean \pm SD $64.4 \pm 5.81 \mathrm{mmHg}$, MRAP range from $70.8-$ $83.3 \mathrm{mmHg}$ and it's Mean \pm SD $76.45 \pm 4.197 \mathrm{mmHg}$ and Max RAP 94.2 - 105.7 mmHg and it's Mean \pm SD $100.5 \pm$ 4.97 $\mathrm{mmHg}$ Shown in Table (5).
Second subgroup of group A were 5 males with acute anal fissure and represent $16.66 \%$ of all patients of the study and $33.33 \%$ of patients of group A and their ages ranged from $23-30$ years old with Mean \pm SD $28 \pm 2.49$ years Shown in Table (2).

Results of the anorectal manometry are RAP resting anal pressure (ranges from $36.8-54.2 \mathrm{mmHg}$ ) and Mean $\pm \mathrm{SD} 50.8 \pm 5.76 \mathrm{mmHg}$, MRAP range from $56.8-69.9$ $\mathrm{mmHg}$ and its Mean $\pm \mathrm{SD} 68.2 \pm 6.87 \mathrm{mmHg}$ and it's Max RAP $61.1-92.5 \mathrm{mmHg}$ and it's Mean \pm SD $67.2 \pm 15.89$ Shown in Table (3). 
Group B were patients with chronic anal fissure and included 11 females with chronic anal fissures and represent $36.66 \%$ of all patients of the study and $73.33 \%$ of the group and their ages range from $25-62$ years old with Mean \pm SD $31.5 \pm 13$ years, Shown in table (8), and the results of the anorectal manometry are RAP resting anal pressure (ranges from $80.1-99.3 \mathrm{mmHg}$ ) and it's Mean \pm SD $88.3 \pm 6.18$, MRAP range from $92.4-123.2$ $\mathrm{mmHg}$ and it's Mean $\pm \mathrm{SD} 102.5 \pm 10.013 \mathrm{mmHg}$ and Max RAP $107.1-144.3 \mathrm{mmHg}$ and it's Mean \pm SD $114 \pm$ 13.2, Shown in Table (9).

Second subgroup of group B were 4 males with chronic anal fissures and represent $13.33 \%$ of all studied patients and $26.66 \%$ of the group with chronic anal fissures and their ages range from $34-44$ years old with Mean \pm SD $40 \pm 3.67$ years. Shown in table (6) and the results of the anorectal manometry are RAP resting anal pressure (ranges from $86.9-89.7 \mathrm{mmHg}$ ) and it's Mean \pm SD $88.65 \pm 1.05$, MRAP range from $97.7-102.1 \mathrm{mmHg}$ and it's Mean \pm SD $100.6 \pm 1.87 \mathrm{mmHg}$ and Max RAP 107.5 - $121.4 \mathrm{mmHg}$ and it's Mean \pm SD $117.3 \pm 6.87$, Shown in Table (7).

\section{Discussion}

Anal fissure is proctological disorder that affects 10$15 \%$ of patients who complain from anorectal disorders as more than $30 \%$ of people complain from proctological disorders at least once in their life [1].

So this is a common anal disorder that affects both females and males with no gender preference and can affect any ages but more common in younger and middle ages.

Some hypothesis in the past supposed that hypertensive anal tone factor is one of the corner stones that lead to development of anal fissure, while on the other hand some manometric studies failed in proving that.
Some other authors found hypertensive resting anal pressure in chronic anal fissure as [9] , [10], [11], [12], [13], [14],[15], [16]

Meanwhile Some other authors found normotensive resting anal pressure in chronic anal fissure as [17], [18], [19], [20]

And a study found $82.3 \%$ of patients with chronic anal fissure had hypertensive resting anal pressure and $17.7 \%$ had normotensive or hypotensive resting anal pressure [21].

In our study we were able to judge if anal hypertonia is a primary or secondary factor (does anal hypertonia causes anal fissure or is it vice versa) or cause or effect of anal fissure.

Knowing this information helps us to specify and choose treatment type (medical or surgical and prognosis of each line of treatment).

Our study was conducted at Benha University in general surgery department in colorectal unit and included 30 patients. Half of them had acute anal fissure and other half had chronic anal fissure.

All patients with anal fissure have had anorectal manometry as it provides an objective assessment of anorectal sphincter mechanism. It provides more reliable indicator of the anal sphincter tone than what can be achieved by digital examination. The relative contribution of voluntary and involuntary component of sphincter tone can be assessed by anorectal manometry which can differentiate functional disorder from organic anorectal disorder. [7]

All patients with acute anal fissures males and females showed normotensive anorectal manometry (normotensive resting anal pressure). This explains why patients with acute anal fissure in early onset of disease can be treated medically (internal anal sphincter muscle not affected) in stage I anal fissure or grade 1 according to a novel classification of anal fissure by [4]

A novel classification of anal fissure by Wienert et al (2017).

\begin{tabular}{|c|c|c|c|}
\hline Stage & Acute or Chronic & Anal fissure description & Secondary changes \\
\hline I & Acute & & None \\
\hline II & Chronic & Shallow fissure & None \\
\hline II A & Chronic & Shallow fissure & $\begin{array}{c}\text { + hypertrophied anal } \\
\text { papilla }\end{array}$ \\
\hline II B & Chronic & Shallow fissure & + anal skin tag \\
\hline II C & Chronic & Shallow fissure & + cryptitis \\
\hline II D & Chronic & Shallow fissure & + fistula \\
\hline III & Chronic & $\begin{array}{l}\text { Visible deep fibers of internal anal } \\
\text { sphincter muscle }\end{array}$ & None \\
\hline III A & Chronic & $\begin{array}{l}\text { Visible deep fibers of internal anal } \\
\text { sphincter muscle }\end{array}$ & $\begin{array}{c}\text { + hypertrophied anal } \\
\text { papilla }\end{array}$ \\
\hline III B & Chronic & $\begin{array}{l}\text { Visible deep fibers of internal anal } \\
\text { sphincter muscle }\end{array}$ & + anal skin tag \\
\hline III C & Chronic & $\begin{array}{l}\text { Visible deep fibers of internal anal } \\
\text { sphincter muscle }\end{array}$ & + cryptitis \\
\hline III D & Chronic & $\begin{array}{l}\text { Visible deep fibers of internal anal } \\
\text { sphincter muscle }\end{array}$ & + fistula \\
\hline
\end{tabular}


Grade 1: fibers of the internal anal sphincter muscle not visible

Grade 2: deep fissure, fibers of the internal anal sphincter muscle visible

Grade 3: deep, undermined fissure edges

Grade 4: fissure with marginal fistula

Meanwhile 15 patients with chronic anal fissures 13 of them $(86,66 \%)$ had hypertensive anal resting pressure (internal anal sphincter muscle is affected so it leads to anal hypertonia) so lateral internal sphincterotomy is useful in the treatment.

And, only two female cases with chronic anal fissure with skin tags $(13.4 \%)$ showed high normotensive resting anal fissure $(80.1 \mathrm{mmHg}$ and $80.9 \mathrm{mmHg})$. Those patients may not have advantage from lateral internal sphincterotomy but may have advantages from skin tag excision with V-Y plasty.

\section{Conclusion}

We can conclude that acute anal fissure disease is not usually associated with elevated resting anal pressure but chronic anal fissure is usually associated with hypertensive anal resting pressure in majority of patients. These manometric findings may explain why most cases of acute case anal fissure can be treated medically while cases with chronic anal fissure usually need surgical intervention that liberates anal pressure from hypertensive state to normotensive state. we also can predict that patients with chronic anal fissure associated with normotensive resting anal pressure may be treated either medically or surgically without doing internal sphincterotomy.

\section{Recommendation}

Anal manometry has corner stone role in treatment of chronic anal fissure as it participates in decision of treatment helpful in telling us if patient will take benefits from lateral internal sphinctrectomy or not so we recommend doing anal manometry before surgical treatment of anal fissure.

\section{References}

[1] Sanju Dhawan PhD, Sunny Chopra M Pharm ,Nonsurgical Approaches for the Treatment of Anal Fissures.The American Journal of Gastroenterology, Vol.102, PP. 1312-1321,2007.

[2] D.Steven , M.D. Wexner, COMPLEX ANORECTAL DISORDERS, 2005.

[3] L.Sharon Dykes, D.Robert Madoff , Benign Anorectal: Anal Fissure, 2007.

[4] Volker Wienert, Franz Raulf, Horst Mlitz, Anal Fissure.,2017.

[5] N. S. Russell, C. J. K. Williams, W. H. Bulstrode Allum, Bailey and Love's short practice of surgery vol.- 23rd ed. R. C. G. (eds) $282 \times 222$ mm. Pp. 1348 . Illustrated. 2000. London: Arnold... Br J Surg, PP. 87: 1738.,2000.

[6] T.H. Lee, A.E. Bharucha , How to Perform and Interpret a High-resolution Anorectal Manometry Test. J Neurogastroenterol Motil, Vol.22, PP.46-59,2016.
[7] S.C.Patra,Evaluation of Predictive Value of Anorectal Manometry in Assessment of Effectiveness of Sphincterotomy in Fissure-in-Ano. International Journal of current Medical and Applied sciences, Vol. 8(2), pp.27-32,2015.

[8] P.Sileri, A.Mele, V.Stolfi, J Gastrointest Surg , PP. 11: $1541,2007$.

[9] B.D. Hancock , the internal sphincter and anal fissure. Br J Surg, Vol.64, PP.92-95,1977.

[10] L.Jostarndt, D.Nitsche, S.Horstmann , Anal fissure und Sphinkterspasmus. Coloproctology.vol.8, PP.375-379. ,1986.

[11] C.P. Gibbons, N.W. Read, Anal hypertonia in fissures: cause or effect? Br J Surg, Vol.73, PP.443445,1986 .

[12] J.K. Lin ,Anal manometric studies in hemorrhoids and anal fissures. Dis Colon Rectum, Vol.32, PP.839842,1989 .

[13] R.Farouk, G.S. Duthie, Sustained internal sphincter hypertonia in patients with chronic anal fissure. Dis Colon Rectum, Vol.37, PP.424-429,1994.

[14] J.O. Keck, R.J. Staniunas, J.A. Loller, Computergenerated profiles of the anal canal in patients with anal fissure. Dis Colon Rectum, Vol.38, PP.72$79,1995$.

[15] K.D. Horvath, R.L. Whelan, R.W. Golub, Effect of catheter diameter on resting pressures in anal fissure patients. Dis Colon Rectum, Vol.38, PP.728-731,1995.

[16] A.P. Zbar, W.A .Kmiot, B. Aslam,. Use of vector volume manometry and endoanal mag- netic resonance imaging in the adult female for assessment of anal sphincter dysfunction. Dis Colon Rectum .vol.42, PP.1411-1418,1999.

[17] M.R.B .Keighley, Y .Arabi, J. AlexanderWilliams, Anal pressures in haemorrhoids and anal fissure. Br J Surg, PP. 63:665, 1976.

[18] M.R.B. Keighley, Y. Arabi, J. AlexanderWilliams , Anal pressures in haemorrhoids and anal fissure. Br J Surg 63:665, 1976.

[19] H. Abcarian, S .Lakshmanan, D.R. Read, The role of internal sphincter in chronic anal fissures. Dis Colon Rectum, Vol.25, PP.525-528,1982.

[20] J. Braun, T.Raguse ,Zur pathophysiologischen Rolle des inneren Analsphinkters bei der chronischen Analfissur. Z Gastroent, Vol.23, PP.565-572,1985.

[21] N.BESHOY NAEEM , Role of Anorectal Manometry in Anal Fissure and Outcome of Tailored Lateral Sphincterotomy in Hypertensive Internal Anal Sphincter: A Modified Minimal Invasive Technique. Med. J. Cairo Univ, Vol.86, No. 7, December, PP.4219-4225, 2018. 